\title{
Is there still a role for rationality in human affairs?
}

\author{
Samiul Parvez Ahmed ${ }^{1}$, Mohammed Tanvir Zubair Ahmed ${ }^{2}$ \\ ${ }^{1}$ School of Business, Independent University, Bangladesh (IUB), Dhaka, Bangladesh \\ ${ }^{2}$ Department of Business Administration, World University of Bangladesh (WUB), Dhaka, Bangladesh
}

\section{Email address:}

samiul@iub.edu.bd (S. P. Ahmed)

\section{To cite this article:}

Samiul Parvez Ahmed, Mohammed Tanvir Zubair Ahmed. Is there Still a Role for Rationality in Human Affairs? International Journal of Philosophy. Vol. 2, No. 1, 2014, pp. 15-20. doi: 10.11648/j.ijp.20140201.12

\begin{abstract}
In social science, the wider epistemological debates regarding polarizing perspectives of rationality (explanation through deterministic approach) and interpretive understanding (understanding through non-physical human mind) in explaining or making sense of lifeworld or social system have been critically examined in this paper. In doing so, this article explores Habermas's Theory of Communicative Action (rationality in socially depended situation) and psychological (strategic action) Game Theory (a deterministic model for rational choice) and, hence, identifies an intriguing link between instrumental/mechanistic and non-instrumental issues regarding rationality concept.
\end{abstract}

Keywords: Rationality, Natural Science Vs Social Science, Instrumental and Non-Instrumental Rationality

\section{Natural Science Vs Social Science}

Social science is all about making sense of social life, or in broad sense the lifeworld, where all human beings are acting, or more specifically interacting for their existence, survival, and advancement. To get an insight of any social phenomenon or even the social system as a whole, we need a method that will make sense of events. In the way of making sense about worldlife, the philosophy of social science raises epistemological issues: scientific explanation versus interpretive understanding [1]. The former one deals with the term, rationality, instrumentally whereas the later one puts more focus on normative and moral aspects of human in social world. From this perspective, these two methods, explanation and understanding, are associated with complex arrays of issues and this paper will focus on them from major issues of rationality. Firstly, the analysis requires clarification of the two terms explanation and understanding.

The concept of explanation comes from 'natural science' where explanation is defined as a method based on rational reasoning to identify the causal relationship of any phenomenon. The naturalists, who are on the 'science' side of social science, claim that ontology is naturalistic and they defend their view on the theme being that, human being and their intellectual moral faculties belongs to nature, thus both of them must be governed by the law of nature [1]. Similar, view can be found in Spinoza's conviction about humanity where he stated 'human actions are natural events, like the actions of clouds or rainstorm' [2]; he further added, 'to understand them is to see them as necessary, determined by the unchanging nature of God' [2]. These views actually lead to deterministic approach to make sense of social events. Determinists are the proponents of the instrumental rationality concept.

Different views can be found among the anti-naturalists who think that human activities are grounded into non-physical human mind which is not guided through such deterministic natural laws. This view can also be seen in Descartes's thinking about human body and mind; where he defined totality of human being not as a physical continuum but which also 'posses a soul, an immaterial substance ... a finite imitation of the infinite substance which is God' [2]. This is the Cartesian Dualism, that the human being is a physical substance along with mind or soul that limits the mechanical explanation of human being [2]. Thus the widely accepted notion to interpret social world, 'understanding', is proposed by the anti-naturalists, as a process of comprehension of knowledge of social life by being within the system. They also have their own version for rationality.

\section{Human as Rational Being}

It is difficult to clearly define rationality in social science. The neoclassical economic viewpoint is for rationality is that--an action is rational if 'it is the best way for the agent to realize his or her goals' [3]. This view emphasizes on 'the appropriate means' to reach a desired end (goal). In the branch of logic, Aristotle takes somewhat a similar stance 
for rationality as 'a choice is desire and reasoning with a view to an end' [4]. In a similar vein, Bertrand Russell has claimed that 'reason' 'signifies the choice of the right means for the end that you wish to achieve' though he further added 'it has nothing whatever to do with the choice of ends' [5]. These views mainly focus on means and do not say much about outcome of the action or choice.

To get a bit clearer picture we may look into the rational choice theory, a theoretical framework to interpret human affairs, where it claims that human actions are rational. The rational choice theory invites us to

'understand individual actors (which in specified circumstances may be collectivities of one sort or another) as acting, or more likely interacting, in a manner such that they can be deemed to be doing the best they can for themselves, given their objectives, resources, and circumstances, as they see them' [6].

There are also various forms of rationality each of which is based on their own reasons. Another view to rationality is that, 'rationality for a person to take into account the consequences of his or her actions' [7]. This view argues that not only the positive outcome makes an action rational, negative outcomes can also be considered as rational as long as individuals take the accountability of their actions and can justify it from their perspectives. As an example, it is rational for a smoker to smoke a cigar if he knows that otherwise the inner dissatisfaction will result in an unproductive day for him [8]. This is an extreme example but relativism does exist in rationality. Rationality judgment of a particular action depends on individual's own preference which may not be conceivable by others due to differences in norms, values and above all, inner-selves. This is somewhat consistent with Weber's study of Protestantism and capitalism where Weber 'implicitly assumed that persons act purposively toward a goal, with the goal shaped by values and preferences', which might be unique to every person [9]. Moreover, rationality of action or goal depends on persons' values embodied in Calvinism ${ }^{1}$ as well. In addition, one's utility maximization (that can also include psychological contentment) can be different from mere (mathematical) economic benefit maximization; thus sometimes what is ordinarily described as non-rational or irrational is merely because of observer could not see from the actors' perspective [9]. From the actors perspective may be the action is rational. Thus it is important to 'understand the intended goal and how the actions were seen by the actor to contribute to that goal' [9]. This issue is nicely dealt by Hume; in his assertion that desired goal is the Passion, and passion can never be unreasonable [4]. He also added that passion can be reducible to single dimension of utility, that is, seeking appropriate way to satisfy pre-existing passion is equivalent to maximization of utility. But Oakeshott strongly objects this kind of view that all passions are reasonable. He substitutes the instrumental conception of

${ }^{1}$ The actions of an individual depend not only on preferences or values but also on opportunities provided by the environment [9]. rationality by saying:

"practical human conduct may be counted 'rational' in respect to its faithfulness to a knowledge of how to behave well" [5].

The statement focuses more on moral philosophical aspects to understand human behavior. From this view, an appropriate mean leading to a successful achievement of a particular desire may not be rational unless until the overall behavior is worthy of praise. From a similar stance, a very naïve definition for rational behavior would be a behavior that means 'anything from reasonable, thoughtful, or reflective behavior to wise, just or sane actions' [10].

Efforts are always there to define human being as rational being though appropriate way is difficult to construct. A lot more issues are associated with the rationality concept that the next section follows.

\section{The Rationality Debate}

The discourse analysis of rationality shows its paradoxical nature in social world. The existing large volume of rationality theories have debates within themselves basically due to polarization of instrumental and non-instrumental perspectives among the proponents of rationality. To understand the debates of rationality, it will be helpful to look into the nature of irrationality. Is irrationality simply means socially unacceptable behaviors? Or individual error/wrong decisions? Or, decisions/actions associated with negative/unwanted/unintended outcome or outcome leading to zero/negative/less than optimal utility? All of these may be the different features of irrationality or may be not; depends on how we look at various incidents. Let us examine some situations where these forms of irrationality issues are captured.

In their work, Kahneman, Tversky, and others have shown that people cannot act at full rationality because their actions are subject to systematic biases [9]. Example would be overestimation of probability of an unlikely event ${ }^{2}$. They termed this type of behavior as less than rational behavior. Coleman [9] has explained few irrational behaviors of people, such as human perceptions; e.g. about some elements (or information) based on which he/she has to make a choice. In such situations people sometimes inclined towards irrelevant elements and thus choose the wrong decision [9]. He also mentions another case, succumbed to temptation, where people carry out some actions which are not to be carried out from rationality point of view; Schelling termed this type of behaviors as 'loss of command from one part of the brain to another' [8]. Another deviation case is peoples' impulsive (without goal in mind) actions that results into unwanted outcomes.

Secondary consequences ${ }^{3}$ (unintended outcome) may occur even the actors are rational. This can be seen from

\footnotetext{
${ }^{2}$ People tend to overplay long shots in betting on races or choose to play a lottery having a larger prize but a lower expected value than another lottery [9]. ${ }^{3}$ Secondary consequences subvert the intended rational outcome [11].
} 
Weber's birth of capitalism view, where he stated that the 'capitalism is born from the unanticipated consequences of a large number of rational individuals believing in the protestant ethic' or for Marx, 'capitalism dies from the unanticipated consequences of each rational capitalist investing in capital-intensive machinery' [11].

Last but not least is the role of emotions (love, aggression etc) that override the logical sense of human being and that leads to irrational outcome of action; as Socrates says 'love is an irrational desire which overcomes the tendency of opinion towards right' [5].

Some authors tried to find out reasons of such irrational behaviors. 'Rationality constraints of human' is one reason that misleads people from logical path. As all the rational theories assume that the actors have certain level of intelligence, but in reality the level might vary; thus limitations exists. These limitations are exposed in complex strategic situations where double contingency of action prevails [9]. Thus individuals with imperfect intelligence will be in a difficult state to act optimally in such situations. Or, 'actors may hold incorrect beliefs about the consequences of their actions' [10]. At times, individuals with perfect intelligence may take less rational decision because informed decision-making can be too costly in real life. Sometimes actions of an individual may involve other persons, where achieving ones' goal may involve others' decisions or actions in the process and it is not possible for an individual to guess how others will react; that is it is difficult to foresee the consequences with perfection. Then individual has to rely on subjective beliefs and then the objectivity of action cease to apply. In turn, 'rational, deductive reasoning - deriving a conclusion by perfect logical processes from well defined premises-itself cannot apply' [12].

Addictive behavior is another reason why people do irrational things. In this state, people perceive greater increment of pleasure from a substance, probably harmful, the more of it they consume. Actually these irrational behaviours or less rational behaviour appear because the organization of self is more complex than is assumed for the unitary actor in rational-choice theory' [9]. Thereby, considering the limitations of individuals (e.g. intelligence or cognitive limitations) and environmental constraints, behavioural economists often term rationality as bounded rationality.

Another reason for irrational behaviour would be uncertainties of life. When individuals try to maximize expected utility and there are uncertainties prevail in the environment, the expectations are subject to probability (error might be there). Then, if the least expected incident happens, the individual deemed to be just unlucky rather than saying that the decision was irrational [10].

From the above stand point, it can be argued that the rational choice theory or utility maximization theory are developed basically on narrowly-defined rationality concept where it does not consider softer-side of human behaviour or odd factors or unanticipated incidents of life (as mentioned earlier); it would be too complex to include all these factors to develop such models. Actually, rational choice theory is preferred

'not as a descriptively accurate (realistic) model of individuals or their interactions, but as a simplification thereof designed to render highly complex mechanisms which cannot be observed directly theoritically tractable.' [6].

In the following sections we will look into two specific theories: Habermas's Theory of Communicative Action and Game Theory in light of rationality debates. The former one tries to blend instrumental aspects with non-instrumental aspects to explain human affairs. And the later one explains human behaviour in strategic situations or interdependent situations.

\section{Theory of Communicative Action: A Societal Approach to Rationality}

Habermas focuses on the convergence of theoretical social science of modern societies (particularly modern enlightenment rationality) and normative philosophical basis to a single integrated theory. To develop such theory he aimed at achieving three distinctive features: 'it must be explanatory, practical, and normative, all at the same time' and in addition to that he attempted to develop a more 'modest, fallibilist, emprical account of the philosophical claim to universality and rationality' [13]. He claimed that enlightenment rationality is monolithic that 'failed to do justice to those philosophic and historical tendencies' and thus he reconstructed the rationality that is based on public communication--communal rationality [14].

At this stage, his speech act theory was crucial to show that rationality actually grounded in competent communicative actions. According to Habermas, communicative action is the verbal or non-verbal interaction between two or more actors who

'seek to reach an understanding about their action situation and their plans of action in order to coordinate their actions by way of agreement' [15]

In the above statement the plans of action means that the actors must have 'performative attitude' in the communicative process so that people gradually, through argumentation and justification, can reach to a mutually respectful agreement-reach an understanding. Actually, engaging in this sort of interaction with such practical attitude is the communicative action. The theory assumes that the rationality is inherent within the communication process, that the rationality is 'how speaking and acting subjects acquire and use knowledge'; it is not just holding adequate knowledge [13]. In other words communicative rationality is 'how does employment of language in contexts of interaction produce mutual agreement on a course of action' [16]. According to Habermas's theory of communicative action: 
'In context of communication action, we call someone rational not only if he is able to put forward an assertion and, when criticized, to provide grounds for it by pointing to appropriate evidence, but also if he is following an established norm and is able, when criticized, to justify his action by explicating the given situation in the light of legitimate expectations' [16].

Here Habermas defined the rationality in the context of communicative action. The rationality of communication depends on speaker's implicit guarantee that one could justify his/her statement from normative, practical and legitimate points of view. This implicit guarantee is also known as validity claim of speech act that it should be sincere, factually true and socially appropriate. 'A speaker can rationally motivate a hearer to accept his speech-act offer' if the implicit guarantee to satisfy the validity claim is present [17]. Thus speaker's knowledge competencies and communicative performance are vital to make the speaker as rational actor in the communication process.

Habermas also compared his communicative action theory with other action theories to prove superiority of his approach. He identified various types of actions; these are teleological or goal oriented action where decisions are based on means-end rationality, strategic action that considers the behaviors of other goal-oriented people while trying to achieve one's own goal, normatively regulated action where actions are based on common social values. He criticized the rationality claim of these actions as each of these actions cannot address the three important areas, objective world, subjective world and social world at the same time. But, the communicative action can relate to objective world, subjective world and social world all together [15]. The widely accepted rationality concept that is only based on achieving goal (or maximizing utility) is myopic. He argued that once we incorporate social perspective within the rationality concept, any purposive action leading to mere self-fulfillment does not hold as rational anymore. Once we incorporate social concept, the rationality concept becomes more complex. 'I can no longer say, for example, that what is true or good is what makes me feel good' [15]. Thus communicative action theory is more comprehensive as it brings divergent approaches (natural, cultural, or hermeneutic) under one roof [13].

Thus, from Habermas's point of view all human interactions are rational, in the social settings, if inherent assumptions hold.

\subsection{Criticisms of Communicative Rationality}

One of the major assumptions of Habermas's theory of communicative action is that the actors are competent enough to communicate rationally, or satisfy the validity claims. But in reality what if the actors do not have competencies for such communication? Or have lack of proper knowledge to justify one's statement or argument? Then the inherent rationality ceases to exist or probably actors become irrational. Lack of interactive competencies may lead to distorted communication as well. Moreover, it is difficult to ignore the substantial body of theory that suggests that all social actions are strategic and they are geared toward achieving self-interest.

Another major criticism of Habermas's model:

'both models of action (communicative and strategic) impute to the actors a capacity for setting ends and for goal-oriented action as well as an interest in executing their own plans for action' [15].

From this viewpoint, communicative action and strategic action becomes indistinguishable. Though, Habermas refutes this objection by pointing out that, in communicative action the goal is to reaching understanding beyond mere objective world; but goal achievement is there.

In the following section we will discuss the strategic action theory or the game theory to understand the nature of human affairs in interactive situations where decisions are interdependent and, at the end, we will try to develop a game theory incorporating Habermas's communicative action theory.

\section{Rational Choice in Strategic Situation: Game Theory \& Theory of Communicative Action Together}

Here we will focus the game theory on how rationality works in game theory rather than going into the details of the mathematical process of it. Game theory has been developed to understand or explain certain social situations where individual's decisions are interrelated with others. In such social situations, generally known as strategic situations, everyone must consider others' decisions before selecting his or her own decision. In formal definition, game theory

is a theory of interdependent decisions-when the decisions of two or more individuals jointly determine the outcome of a situation. The individuals can be persons or collective entities that make consistent choices' [10].

It is generally assumed that individuals are rational actors having common knowledge and who try to achieve their goal to maximize personal utility. But here individuals' choices are not free; choices are constrained by one another's action and, thus, achieving individual goal might not be possible here. In the game theory, out of all possible alternatives, one chooses the best option (might be different from the original intended goal) because one knows that with current position no one 'can improve its own position on its own' as the situation is beyond the control of the actors individually [10]. Thus in game theory, the rationality means choosing the best option under constrained situation.

We will try to develop and solve a two-person zero-sum game where the objective would be to incorporate Habermas's theory of communicative action within the game. This is a case of social situation where two parties interacts, thus Habermas's communicative action theory can be incorporated. And, for the time being, we are accepting the rationality defined by the economists for game theory that is the utility approach to rationality, though it does not 
match with Habermas's rationality. But in the final part we will discard economic rationality and will bring Habermas's rationality concept to conclude the game.

Here the players try to pursue their goal jointly and one's action depends on the other player's action. Here the individual choices are two forms of communication options. Now, let us look into the foundations of Habermas's communicative action theory where it focuses on reaching understanding through 'sincere and honest' communication having internal validity; let this be option one. And let, 'manipulative' communication be the second choice. Finally, let us assume that the two players have common knowledge and equal competence. The probable $2 \mathrm{X} 2$ option matrix with the respective utilities is given below (figure 1: the higher number represents higher level of utility and the first number in the brackets represents utilities of player1 and the second one for player2):

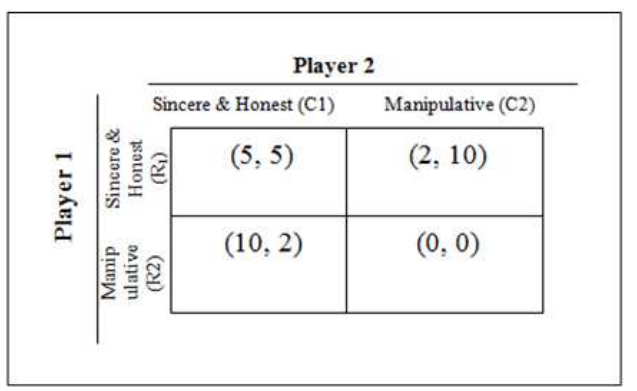

Figure 1. two person strategic game.

Player1 knows that if he/she chooses R2 and player2 goes for $\mathrm{C} 1$ then he/she will get maximum utility. But player1 also considers the fact that player 2 also has equal knowledge and competencies and might be thinking in the same way as he/she does. In that case player 2 would go for $\mathrm{C} 2$. Then both of them will end up with no cooperation that is zero utility. Player2 also thinking in the same way. There is no dominant strategy and no equilibrium from this perspective.

How can they reach to equilibrium? Equilibrium can only be established if we reconstruct the rationality concept. Let, Habermas's reaching understanding by being 'sincere and honest' is the rationality here, not utility maximization. This, new dimension of rationality will push them together to top-left cell as 'no agreement' is not rational anymore; and thus top-left cell is the only option--equilibrium. This also satisfies Habermas's communicative action theory that people will act in such a way so that they can reach to understanding (agreement). All other cells represent irrational options from Habermas's conception. In the above game if we do not accept the rationality formulated by Habermas, there would be no equilibrium ${ }^{4}$.

Now, let us reconstruct the payoff matrix by considering Habermas's rationality concept. According to Habermas's rationality point of view, the highest or optimal utility can be

\footnotetext{
${ }^{4}$ A similar explanation is given, though not from Habermas's perspective, by Rapoport (with different situation) while describing how in real life 'peace' can be achieved [7]
}

achieved when both the players choose the 'rational' option (top left cell in Figure 2) because reaching understanding is the inherent motive of communicative action theory and it is achieved in the top left cell of figure 2 . Any deviation by any player will result in less than optimal utility for both the players because that violates the reaching understanding objective. And the fourth option (right bottom cell) is same as before; that is no agreement option sustains when both of them are manipulative. Thus, in ideal situation, rational people will always stick to the reaching understanding option (top left cell) and that is the equilibrium of the game.

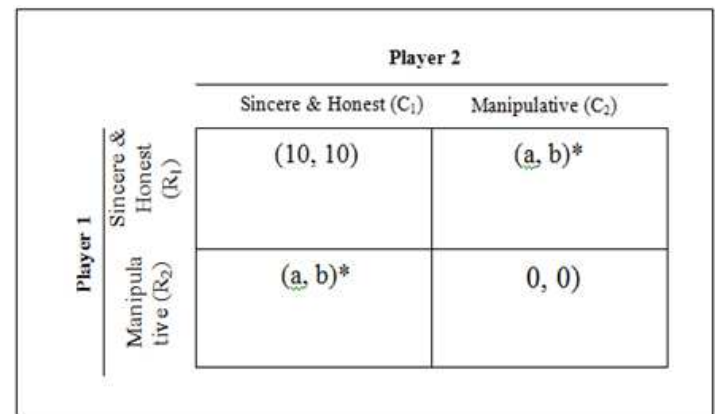

Figure 2. two person strategic game with Habermas's Rationality Consideration ${ }^{5}$

\section{Conclusion}

It is somewhat true that the paradoxes of rationality make it complex to answer our central question clearly--Is there still a role for rationality in human affairs? Actually, the social science itself is trapped into this rationality conundrum. Various thoughts have been generated by economists, philosophers, sociologists, mathematicians just to give a concrete shape of rationality that we have seen earlier. With various perspectives, similar human affairs can be categorized either as rational or irrational. As discussed earlier, the confusion arises with means and ends--which one is crucial to define rationality? Is it just maximization of own interest (utility) is rationality or socially acceptable, sensible behavior is rationality? If we consider the various social aspects (values, norms etc.) to define rationality then these factors themselves are contestable sometimes.

A broader definition to individual rationality may help to explain certain human affairs from rationality point of view. Like, if achieving desired goal, purpose or passion generates maximum utility then probably all human actions will be deemed as rational, as there can be no action without purpose or motive; whatever the purpose is. But the obvious criticize of this view is that what if the purpose itself is not socially acceptable? These are the regular debates that going around rationality issues. Moreover, if we can rationally explain the irrational actions of humans ${ }^{6}$, then the rest becomes rational if the rationality and irrationality jointly comprise the total set of behaviors. Then we can say that, set

\footnotetext{
5 *In this figure, a or $\mathrm{b}<10$; because these are results of 'irrational' choices and these options do not match with the objectives of the players

6 That we have discussed earlier in 'The Rationality Debate', section 3.
} 
aside those unusual or irrational cases, all human affairs are generally rational. Thus we can say that yes, it is true that rationality does have important role in human affairs but we are still not in position to clearly delineate the nature of it because of the inherent issues associated with it.

Lastly, based on our Game Theory model and its link to Habermas's Communicative Action Theory, it can be argued that there is a close link between purely deterministic approaches to rationality with the anti-naturalistic theories to rationality (interpretive understanding). To be more specific, it can be concluded that the deterministic and interpretive understanding theories regarding human rationality have dual role in making sense of the lifeworld or social system.

\section{References}

[1] Hollis M., (1998), 'Philosophy of Social Science' in the The Blackwell Companion to Philosophy, Bunnin $\mathrm{N}$ and Tsui-James E. P. (eds), (1998), Oxford: Blackwell Publishers.

[2] Ross G. and Francks R. (1998), 'Descartes, Spinoza and Leibniz' in the The Blackwell Companion to Philosophy, Bunnin N and Tsui-James E. P. (eds), (1998), Oxford: Blackwell Publishers.

[3] Roberts M., (1996), Analytical Marxism-A Critique, London: Verso Publishers.

[4] Allingham M. (1999), Rational Choice, London: Macmillan Press Limited.

[5] Black M. (1990), Perplexities: Rational Choice, the Prisoner's Dilemma, Metaphor, Poetic Ambiguity, and other Puzzles, USA: Cornell University Press.

[6] Abell P. (2000), 'Sociological Theory and Rational Choice Theory' in the The Blackwell Companion to Social Theory, Turner B.S. (ed), (2000), Oxford: Blackwell Publishers.

[7] Rapoport A. (1998), 'Counterproductive Rationality', in the Game Theory, Experience, Rationality: Foundations of Social
Sciences, Economics and Ethics, Leinfellner W and Kohler E. (eds), (1998), Netherlands: Kluwer Academic Publishers.

[8] Schelling T. C., (1998), 'Rationality Coping with Lapses from Rationality', in the Game Theory, Experience, Rationality: Foundations of Social Sciences, Economics and Ethics, Leinfellner W and Kohler E. (eds), (1998), Netherlands: Kluwer Academic Publishers.

[9] Coleman J. S. (1990), Foundations of Social Theory, USA: The Belknap Press of Harvard University Press.

[10] Morrow J. D. (1994), Game Theory for Political Scientists, New Jersey: Princeton University Press.

[11] Barnes T. J. and Sheppard E. (1992), Is there a Place for the Rational Actor? A Geographical Critique of the Rational Choice Paradigm, Economic Geography, Vol. 68, No. 1, (Jan., 1992), pp.1-21.

[12] Arthur W. B. (1994), 'Inductive Reasoning and Bounded Rationality', American Economic Review (Papers and Proceedings), Vol. 84, (1994).

[13] Bohman J. and Rehg W. (2007), 'Jürgen Habermas', in the The Stanford Encyclopedia of Philosophy, Zalta E. N. (ed.), (Spring 2008).

[14] Bernstein R. J. (2005), The New Constellation: The Ethical-Political Horizons of Modernity/Postmodernity, Cambridge: Polity Press in association with Blackwell Publishers Limited.

[15] Outhwaite W. (1994), Habermas A Critical Introduction, Cambridge: Polity Press in association with Blackwell Publishers.

[16] White S. K. (1995), The Cambridge Companion to Habermas, Cambridge: Cambridge University Press.

[17] Callinicos A, (1991), Against Postmodernism: A Marxist Critique, Cambridge: Polity Press in association with Basil Blackwell. 